\title{
Adaptation Model For East Nusa Tenggara Students To The Teaching Learning Process At Ikip Budi Utomo Malang In The Covid19 Pandemic Era
}

\author{
* Yulita Pujiharti, \\ Lecturer at IKIP Budi Utomo Malang and Student of Economic Education Doctoral Program, Faculty of Economics, \\ State University of Malang, e-mail: ladyaribet@gmail.com \\ **Cipto Wardoyo \\ Lecturer at Economic Education Doctoral Program, Faculty of Economics, State University of Malang \\ *** Titik Purwati \\ Lecturer at IKIP Budi Utomo Malang \\ *****Amanah Agustin \\ Lecturer at IKIP Budi Utomo Malang \\ ***** Loesita Sari \\ Lecturer at IKIP Budi Utomo Malang
}

DOI: 10.29322/IJSRP.11.06.2021.p11479

http://dx.doi.org/10.29322/IJSRP.11.06.2021.p11479

\begin{abstract}
Students from East Nusa Tenggara bring the culture they have lived since they were born until they graduated from high school. Therefore, when these students enter and study, they must also adapt to the teaching and learning patterns of the lecturers who in the teaching and learning process always follow the times, especially in this era of the COVID-19 pandemic, all learning processes must be based on online technology. This study aims to find out (1) What is the cultural background of Budi Utomo's IKIP students from NTT (2) What is the pattern of adaptation of NTT students to the teaching and learning process in the era of the COVID-19 pandemic

This research includes qualitative research usingmethods phenomenological. The research subjects were students from East Nusa Tenggara and 35 people were randomly selected based on their regions such as from Manggarai, Adonara, Malacca and others as informants. The research location is at IKIP Budi Utomo Economic Education Study Program. The research instrument was an open questionnaire and a structured interview using google form, google classroom and whatshap group with students from East Nusa Tenggara and randomly selected. Data analysis used Seiddel's inductive qualitative data analysis technique.

The results of the study revealed that the cultural background of students from East Nusa Tenggara which was carried away in their teaching and learning process while in high school was through mixing languages, between regional languages and Indonesian, then harsh punishments and classical "behavioristic" teaching patterns that are still widely used. The difficulty they face when adapting to the teaching and learning process is when they write scientific papers or papers. In this era of 4.0 and all online, they find it difficult to take online classes due to internet facilities and limited mastery of technology. And they adapt or find it difficult at the beginning of online lectures after that they can adapt well. The pattern of adaptation of NTT students to the teaching and learning process based on Robert K Merton's theory is the pattern of habituation.
\end{abstract}

Index Terms:Adaptation Model, Prose and Learning, Student, Era covid19

\section{IINTRODUCTION}

This 19 Covid pandemic accelerate the learning process must use the latest technology, with the online system, due to this pandemic era of education and learners can not meet directly. Therefore, this pandemic era has accelerated the era of the learning revolution from classic to online learning. Most of the students studying at IKIP Budi Utomo are students from East Nusa Tenggara. Where they migrated from their hometowns to study at IKIP Budi Utomo. Students studying at private LPTKs certainly have very different characteristics from students studying at State LPTKs, because on average they have the ability and willingness to think below state

This publication is licensed under Creative Commons Attribution CC BY. 
students. And since they were elementary school to high school students in NTT they applied the culture and local wisdom that existed in their respective areas. Therefore, when these students enter and study at IKIP Budi Utomo, they must also adapt to the teaching and learning patterns of the existing lecturers. Therefore, to understand a course and complete a whole series of lectures they also need extra treatment and ability from the teacher. This situation is compounded by the covid 19 pandemic, which requires them to get to know technology faster. This study aims to find out. This study aims to find out (1) What is the cultural background of Budi Utomo IKIP students who come from NTT (2) How are the adaptation patterns of NTT students to the teaching and learning process at Budi Utomo IKIP Malang in the era of the covid 19 pandemic

\section{LITERATURE REVIEW}

Culture is a way of life that develops, is shared by groups of people, and is passed down from generation to generation. This culture is formed from many complex elements, including religious and political systems, customs, tools, language, buildings, clothing, and works of art. Culture can be defined as a collection of several life experiences that exist in a particular group of people. The life experience in question can be in the form of beliefs, behavior and lifestyle of a society. Parsudi Suparlan, said that culture will underlie all behavior in society, because culture is human knowledge that is entirely used to understand and understand the environment \& experiences that occur to him (Suparlan, 1993).

East Nusa Tenggara is a province inIndonesiawhich is in theclusterLesser Sundaand is included inthe Nusa Tenggara Islands. The province which is commonly abbreviated as NTT has 21 regencies/cities. At the beginning of Indonesia's independence, this archipelago was part of the LesserProvinceSunda. which has its capital city Singaraja, now consists of 3 provinces (consecutively from the

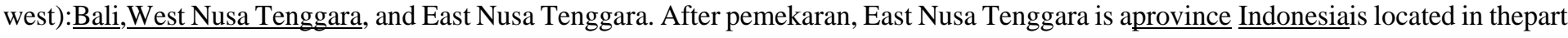
ofsoutheasternIndonesia. NTT is known as the most tolerant area among human beings. This is all because NTT has a variety of people. Whether diverse ethnicity, culture, religion and race. NTT people have a culture such as dances or arts. The hallmark of NTT is its Komodo Island which has entered the 7 Wonders of the World. There are also woven fabrics which are usually made by hand. This woven fabric is also commonly used for traditional events. . And what is no less distinctive is that in almost every district and city there are rocks from small to large and towering palm trees on beaches such as Lasiana Beach, Kupang.

In educational institutions, in schools and universities, it is always found that there is a teaching and learning process, namely students learn and teachers carry out learning. Learning is a process of activities that produce behavioral changes, both cognitive, affective, and psychomotor in students. While learning is the arrangement of information and the environment to facilitate and realize learning situations in students. As one of the private universities whose output is a qualified "Teacher", IKIP Budi Utomo Malang helped to make the government program a success by providing affordable and quality education. Most of the students studying at IKIP Budi Utomo are students from East Nusa Tenggara. Where they migrated from their hometowns to study at IKIP Budi Utomo. Students studying at private LPTKs certainly have very different characteristics from students studying at State LPTKs, because on average they have the ability and willingness to think below state students. Therefore, to understand a course and complete a whole series of courses they also need extra treatment and ability from the teacher.

After the emergence of the Covid-19 outbreak in the hemisphere, the education system began to look for an innovation for the teaching and learning process. Moreover, the Circular no. 4 of 2020 from the Minister of Education and culture who recommends that all activities in educational institutions must keep a distance and all material delivery will be delivered at their respective homes. (diknas.oukab.go.id). With the Learning Method 1) Project based learning has the main goal of providing training to students to be more able to collaborate, work together, and empathize with each other 2) Online Method This method utilizes online networks, and can make students creative using existing facilities 3 ) Offline method is a learning model that is carried out outside the network. In a sense, this one learning is carried out face-to-face by taking into account the zoning and applicable health protocols. 4) Home visit is one of the options in the learning method during this pandemic. 5) Integrated Curriculum This method will be more effective when referring to the project base, where each class will be given a project that is relevant to the related subject. 6) The blended learning method is a method that uses two approaches at once. 7) Learning through radio is a learning innovation during the covid-19 pandemic in Ogan Komering Ulu district. This method is a collaboration between the Education Office of the Ogan Komering Ulu district and Radio Sukses which is a local government radio.

Merton in Suci Wulandari (JOM FISIP, Vol 6, 2019) puts forward a typology of ways of adapting to situations, namely conformity, innovation, ritualism, self-isolation, and rebellion (the last four are deviant behavior). 1. Conformity This method is the most widely used method. Here, the behavior follows the goals set by the community and follows the method determined by the community to achieve these goals and pass the exam to continue the higher education level. 2. Innovation is a way in which behavior follows the goals set by society but uses methods that are prohibited by society. 3. Rebellion This adaptation pattern, people no longer recognize the existing social structure and seek to create another social structure. Existing cultural goals are seen as barriers to desired goals. 4. Ritualism A person's behavior has left the cultural goals but still adheres to the way that has been outlined by society. 5. Retreatism In this form of adaptation, a person's behavior does not follow the cultural goals and also does not follow the way to achieve cultural goals.

\section{DATA AND METHODOLOGY}

This research is a qualitative research withmethod phenomenological. Moleong in his book qualitative research methods (Moleong, 2014) defines phenomenology as 1) subjective experience or phenomenological experience 2) a study of the basic consciousness of a person. Phenomenological research seeks to understand the meaning of an event and its relation to people in certain situations.

The research subjects were Economic Education students of IKIP Budi Utomo who came from East Nusa Tenggara and

This publication is licensed under Creative Commons Attribution CC BY.

http://dx.doi.org/10.29322/IJSRP.11.06.2021.p11479

WWW.ijsrp.org 
35 people were randomly selected based on their regions such as from Manggarai, Adonara, Malacca and others as informants.

The research instrument was an open questionnaire and structured interviews with Economic Education students of IKIP

Budi Utomo who came from East Nusa Tenggara and were randomly selected using google classroom and WA Group about 1) NTT student cultural background 2) NTT student adaptation patterns to the teaching and learning process at the Economic Education Study Program of IKIP Budi Utomo Malang in the era of the covid 19 pandemic.

The data sources in this study were 35 students of the Economic Education Study Program who came from East Nusa Tenggara. With Seiddel's inductive qualitative data analysis technique in Moleong (2014; 248) with the following steps: 1) Taking notes which produces field notes 2) Collecting 3) Sorting 4) Classifying 5) Synthesizing 6) Making an overview 7) Thinking by making categories data has meaning 8) Searching for and finding patterns and relationships and general findings

\section{Cultural Background of Students from NTT}

\section{RESULT AND DISCUSSION}

From the results of interviews and open questionnaires distributed by goggle class to Economics Education students, 35 NTT students were randomly selected spread across West Sumba Daya, Sumba, Flores, Manggarai, Kupang, West Sumba, Atambua, Larantuka, and Adonara found that the way teachers teach in high school is in accordance with the KTSP curriculum. The average teacher teaching technique is still behavioristic, where the teacher explains, asks questions and evaluates. The most dominant culture or local wisdom tucked away when teaching is through language which is usually a mixed language between regional languages and Indonesian. The culture of punishment for those who violate the rules is also mainly due to not entering on time, almost all students experience it, both male and female. The interview also revealed that harsh punishments still occur. Local wisdom is carried in schools such as the Pasola traditional culture of javelin throwing held at schools in Southwest Sumba, carnivals with traditional clothes, schools also teach local wisdom such as making rattan plates and woven mats. In other schools, local dances are also taught to preserve local culture.

So the cultural background of IKIP Budi Utomo's economic education study program students who came from East Nusa Tenggara who were carried away in their teaching and learning process while in high school was through mixing languages, between regional languages and Indonesian, then rather harsh punishments and classical teaching patterns " behavioristic" which is still widely used.

\section{NTT Student Adaptation Model to the Teaching and Learning Process in the Era 4.0 Covid 19 Pandemic}

After entering the world of Higher Education, especially at IKIP Budi Utomo, students from NTT made adaptations to the teaching culture in Malang City, especially in the Economic Education Study Program of IKIP Budi Utomo. Students learn to adapt to "constructivism"-based teaching techniques used by almost all lecturers in the Economic Education Study Program of IKIP Budi Utomo.

Then after the Era of Technology and the Industrial Revolution 4.0 was accelerated by the tragedy of the Covid 19 Pandemic which led students and educators to use online technology massively, causing drastic changes in learning patterns. Where all processes use online technology. Whether it is possible or not, educators and students are forced to adapt to Technology 4.0.

The average difficulty of students is to make a paper or scientific paper and then upload it online where almost all informants state difficulties and are still studying seriously. The positive value is that they adapt quickly and can write papers after 2 to 3 months of studying online at the Economic Education Study Program of IKIP Budi Utomo.

Almost all students answered that they felt the difference in the way lecturers taught at the Economic Education Study Program of IKIP Budi Utomo with their teachers during high school, namely they had to make papers and presentations. Then they had to be brave enough to speak in public to present their papers and had to answer their friends' questions. They think the most difficult process is when they have to answer their friends' questions.

All respondents or informants feel happy to be studying at the Economic Education Study Program of IKIP Budi Utomo with the reasons 1) Malang City is clean and safe from crime 2) Because the IKIP Budi Utomo Campus is comfortable, the building is nice, the semester fees are cheap, the facilities are good and the lecturers are friendly- friendly 3) The environment around the campus or comfortable boarding house The

difficulties they face when adapting to the teaching and learning process at universities, especially in the Economic Education Study Program, IKIP Budi Utomo, are when they make scientific papers or papers, then there are many assignments from each lecturer. And they adapt or find it difficult during the first semester after that they can adapt well.

If described with the theory of Robet K Merton, the adaptation pattern of the students of the Economic Education Study Program of IKIP Budi Utomo is as follows:

Table: Pattern of Student Adaptation in the Teaching and Learning Process at IKIP Budi Utomo Malang

\begin{tabular}{|l|c|c|}
\hline \multicolumn{1}{|c|}{ Adaptation Pattern } & Total & percentage of \\
\hline Compliance(Conformity) & 7 & $20 \%$ \\
\hline Update( Innovation) & 7 & $20 \%$ \\
\hline Familiarity(Ritualism) & 21 & $60 \%$ \\
\hline
\end{tabular}

This publication is licensed under Creative Commons Attribution CC BY.

http://dx.doi.org/10.29322/IJSRP.11.06.2021.p11479

WwW.ijsrp.org 


\begin{tabular}{|c|c|c|}
\hline Runaway(Retreatism) & 0 & 0 \\
\hline Rebellion(Rebellion) & 0 & 0 \\
\hline Total & 35 & 100 \\
\hline
\end{tabular}

Based on the table above it can be concluded that the pattern of adaptation of the students NTT upon teaching and learning in Prodi Economic Education Teachers' Training College Budi Utomo Malang according to Robert K Merton's theory is a "pattern of habit".

\section{CONCLUSSION}

The cultural background of IKIP Budi Utomo's economic education study program students from East Nusa Tenggara who were carried away in their teaching and learning process while in high school was through mixing languages, between regional languages and Indonesian languages, then harsh punishments and classical teaching patterns " behavioristic" which is still widely used.

The difficulty they face when adapting to the teaching and learning process in higher education, especially in the Economic Education Study Program of IKIP Budi Utomo, is to make a paper or scientific work and then upload it online where almost all informants state difficulties and are still studying hard. The positive value is that they adapt quickly and can write papers after 2 to 3 months of studying online at the Economic Education Study Program of IKIP Budi Utomo.. And they adapt or find it difficult during the first semester after that they can adapt well. The adaptation model of NTT students towards the teaching and learning process at the Economic Education Study Program of IKIP Budi Utomo Malang according to Robert K Merton's theory is a pattern of habituation.

\section{REFERENCES}

[1] Degeng, INS, 1991. Characteristics of Various College Student. Research Report. Depdikbud Dikti PTBAU/IUC (World Bank XVIII).

[2] EkoDigdoyo, 2015. Basic Social and Cultural Sciences. Bogor, PublisherGhalia Indonesia,.

[3] Gagne, RM 1985. The Conditions of Learning. New York: Holt Renehart and Winston.

[4] Moleong. Lexy. J. 2012. Qualitative research methodology. Bandung: PT Youth Rosdakarya

[5] Nawawi Hadari. 2005. Social research methods. Yogyakarta: Gadja Mada University Press,

[6] Nurastuti Wiji. 2007. Research Methodology, Yogyakarta: Ardana Media.

[7] Pujileksono Sugeng. 2015. Understanding Socio-Cultural Reality, Malang: Intrans Publishing.

[8] Rat Dominic. 2014. Customary Law in Indonesia An introduction. Surabaya: Laksbang justia.

[9] Raphael, RM, 2000. Humans and Culture in the Perspective of Basic Cultural Sciences. Jakarta: PT RinekaCipta,Cultural

[10] Roger M. Keesing, 1981 Anthropology. PT. Gelora AksaraPritama.

[11] Setiadi Elly M. et al. 2011. Basic Social and Cultural Sciences, Jakarta: Prenada Media Group.

[12] Sugiyono. 2014. Understanding qualitative research. Bandung: CV. Alfabeta

[13] Setiadi \& Kolip. 2011. Introduction to Sociology, Yogyakarta: Kencana Pranada Media Group

[14] Suparlan, Parsudi, 1993. People, culture, and the environment, Jakarta : Raja Grafindo Persada.

[15] Wulandari, S.2019. Woman Convicted Of Killing Adaptation (Correctional Institution of Female Class Ii A Ekanbaru City) Let's Fisip Vol 6: EditionJuly - December 2019

\section{AUTHORS}

First Author : Student of Economic Education Doctoral Study Program, Faculty of Economics, State University of Malang, Lecturer at Economic Education Study Program, IKIP Budi Utomo Malang, e-mail: ladyaribet@ gmail.com

Second Author : Cipto Wardoyo Lecturer at Economic Education Doctoral Program, Faculty of Economics, State University of Malang

Third Author : Titik Purwati Lecturer at Study Program for Economic Education, IKIP Budi Utomo Malang, e-mail: titikpurwati62@gmail.com

Fourth Author: Amanah Agustin Lecturer at Study Program History and Sociology Education, IKIP Budi Utomo Malang

Fiveth Author : Loesita Sari Lecturer at Study Program Economic Education, IKIP Budi Utomo Malang 